\title{
Guidelines for the uniform characterisation of the actinosporean stages of parasites of the phylum Myxozoa
}

\author{
J. Lom ${ }^{1, *}$, J. McGeorge ${ }^{2}$, S. W. Feist ${ }^{3}$, D. Morris ${ }^{2}$, A. Adams ${ }^{2}$ \\ ${ }^{1}$ Institute of Parasitology, Czech Academy of Sciences, České Budějovice, Czech Republic \\ ${ }^{2}$ Institute of Aquaculture, University of Stirling, Stirling FK9 4LA, United Kingdom \\ ${ }^{3}$ M.A.F.F. Fish Diseases Laboratory, Weymouth, Dorset DT4 8UB, United Kingdom
}

\begin{abstract}
It is vitally important that good quality descriptions of actinosporean stages of myxosporeans are produced since these may prove to have a very important role in the taxonomy and classification of the combined myxozoan taxon. Guidelines are therefore presented for the preparation of accurate descriptions of actinosporean stages, and the terminology to be employed in such descriptions is outlined and defined. Actinospore and myxospore should be promoted as terms for the myxosporean and actinosporean spore stages in the myxozoan life cycle.
\end{abstract}

KEY WORDS: Actinosporean - Myxosporean - Myxozoan - Taxonomy

\section{INTRODUCTION}

Following the pioneering work of Wolf \& Markiw (1984), a number of reports have presented direct or indirect evidence that a single myxozoan life cycle exists which consists of 2 phases, myxosporean and actinosporean, appearing alternately in fish and invertebrate hosts (El-Matbouli et al. 1992a, 1995; Appendix 1). Although future research must establish whether a life cycle including myxosporean-actinosporean transformation takes place in all genera, and confirm whether it is applicable to marine as well as freshwater myxozoans, such life cycles are now widely accepted and can thus be regarded as confirmed.

High level taxonomic conclusions have already been made based on the unification of the 2 former classes Myxosporea and Actinosporea (Kent et al. 1994). These authors proposed that the class Actinosporea be suppressed and its genera provisionally reduced to the status of collective groups, except for Tetractinomyxon,

•E-mail: lom@paru.cas.cz which they have tentatively shifted to the myxosporean order Multivalvulida. This was mainly due to the single binucleate sporoplasm of this genus, in spite of the fact that its pansporocysts produce 8 spores, in contrast to all myxosporeans. In addition, Odening (1991) has suggested changes in myxozoan terminology to reflect his belief that oligochaetes represent the definitive hosts in the life cycle. The absolute uniqueness of myxozoan features among protists need not excite protozoologists any longer since recent research has indicated that the whole group should be reassigned to the kingdom Metazoa (Smothers et al. 1994, Schlegel et al. 1996), perhaps to the vicinity of, or directly to, the Cnidaria (Siddal et al. 1995).

Even if we assume that many myxosporean species are synonyms, it can still be expected that there will be a large increase in the number of descriptions of actinosporean stages as more myxozoan life cycles become fully described. As the number of actinosporean stage descriptions increases, it becomes vital that thay be identified accurately in the future and so a precise characterisation of actinosporeans is essential. Poor initial descriptions in the past have created taxo- 
nomic confusion in the former class Myxosporea and there are a number of poor descriptions of actinosporean stages in the literature, many even in recent reports of 2 -host life cycles.

The problem is best addressed by the production of good quality initial descriptions of the developmental stages and mature spores of actinosporeans utilising standard terminology and standardised measurement parameters. As in the case of myxosporeans, the taxonomy of actinosporeans is based almost solely on spore morphology. Despite the suppression of actinosporeans as a separate class (Kent et al. 1994), the morphology of actinosporean stages will almost certainly prove to be a very important criterion in the taxonomy and classification of the combined myxozoan taxon, especially as patterns begin to emerge and descriptions of more species' life cycles are completed. Many more changes are likely to take place in the future over and above those already proposed, since, for example, 3 myxobolids (Myxobolus cerebralis, $M$. pavlovskii and Myxobolus sp.) transform into actinosporean stages previously regarded as 3 completely separate genera, i.e. Triactinomyxon, Hexactinomyxon and Raabeia (Wolf \& Markiw 1984, Ruidisch et al. 1991, Yokoyama et al. 1991), whereas 3 species from distinct myxosporean genera (Ceratomyxa shasta, Myxidium giardi and Hoferellus carassii) all have aurantiactinomyxon actinosporean stages (Bartholomew et al. 1992, El-Matbouli et al. 1992b, Benajiba \& Marques 1993). Indeed, there is recent evidence that there may be phenotypic variation between the actinosporean stages of single myxozoan species depending on geographic location and the oligochaete host, which may in turn result in differential ability to infect hosts from different locations (Urawa et al. 1995).

There is confusion in the literature with regard to the terminology used to describe actinosporean features and development, with several terms being used for the same structure or feature in a number of cases. The terms and definitions of these structures require standardisation to ensure their consistent usage. In the present communication the authors' aim is to define actinosporean stage terminology and outline the important diagnostic and taxonomic features and measurement parameters upon which actinosporean stage descriptions should be based. Janiszewska (1957) presented a brief list of actinosporean terms; however, they are now outdated and reflect the early state of knowledge of these stages (e.g. sporozoites, epispore, capsular thread). Guidelines in this paper complement those of Lom \& Arthur (1989) for myxosporean stages; it is hoped that their application will help to avoid taxonomic confusion in the Myxozoa.

\section{TERMS TO BE USED IN ACTINOSPOREAN DESCRIPTIONS}

Some of the important structures are depicted in Figs. 1 to 10 .

Apex: upper part of spore containing the polar capsules.

Early stages: separate cells with 1 or 2 nuclei preceding pansporocyst formation. They may divide by binary or multiple fission (merogony).

Pansporocyst: constituting 2 or 4 cells, the pansporocyst forms an envelope inside which cell division, gamete formation and fusion to form the zygote, and the division and differentiation of this zygote into spore-producing sporoblasts and spores proceeds (Figs. 6, $7 \& 10$ ).

Polar capsules: in actinospores, pyriform bodies encased within a refractile, thick, double-layered wall and containing a spirally coiled polar filament which upon the proper stimulus (e.g. contact with fish mucus) instantaneously discharges by everting. The remainders of the capsulogenic cell are attached to the polar capsules. The stopper of actinospore polar capsules protrudes through a discharge canal left between the valve cells. In myxospores the filament discharges through a canal which pierces the valve border and does not protrude.

Processes: separated lateroposterior or posterior (= caudal) processes of the valve cells. Caudal processes are often curved and long (up to $500 \mu \mathrm{m}$ in Triactinomyxon ignotum). These processes usually contain the remainders of the valve cell nuclei (Fig. 5) and are delicate rather than rigid. In the pansporocyst the processes appear as telescopically folded membranes (Fig. 10) which swell on release into water.

Spore: multicellular complex built of cells which are differentiated into sporoplasm cells, valve cells and capsulogenic cells. The terms 'actinospore' and 'myxospore' should be promoted at the expense of the more laborious and clumsy 'actinosporean stage spore'/ 'myxosporean stage spore'.

Spore body: part of the spore which contains inside a cavity the sporoplasm and the polar capsules (the cavity was formerly referred to by the obsolete term 'endospore').

Sporoplasm: except for the actinosporean genus Tetractinomyxon, which has a single binucleate sporoplasm (Kent et al. 1994), the sporoplasm of all actinosporeans is a multinucleated plasmodium enclosing one to many daughter secondary cells which are the actual infective germs ('éléments disséminateurs'). These may each be associated with one of the sporoplasm nuclei. When released from the spore, the daughter cells start the infection in the fish. Although sometimes difficult to count, the number of cells within 
Fig. 1 Proposal outlining standard measurements and other features of spores for the recording of the main morphological types of actinospores. (A to C) Triactinomyxon. (A) Spore in side view, $(B)$ the spore body in side view, (C) polar capsule in side view. 1 : length of spore body; 2 : width of spore body; 3 : length of style (in raabeia the 3 valve cells separate right at the end of the spore body without forming a style); 4: width of style; $1+3$ : total length of spore; 5: length of caudal processes (irrespective of curvature); 6 : largest span between the tips of the caudal processes; 7 , 8: length and width of the polar capsule; $\alpha$ : angle between the style and caudal process; $a$, b: different positions of the nucleus of the valvogenic cells; count the number of secondary cells of the sporoplasm (infective germs) and the number of turns of the polar filament coil. In the remaining diagrams only features different or supplementary to those already mentioned are marked: (D) Synactinomyxon in apical view (polar capsules and sutures not marked). 1,2 width and length of the longer caudal process; 3,4 : width and length of the short caudal process. ( $E$ to $G$ ) Sphaeractinomyxon; (E, F) angular spore in side and apical view, respectively; (G) spherical spore in apical view. 1: diameter of the spore body (angle to base); and 2: length of the spore body (diameter and length may be equal); 3 : diameter (width) of spore body in spores with spherical shape (the same as 1); s: suture line (distinct or indistinct). ( $\mathrm{H}, \mathrm{I}) \mathrm{Dia}$ gram of aurantiactinomyxon spore in side and apical view, respectively. 1 : diameter of the spherical spore body; 2 and $3_{1}$ : length and width of the caudal process as seen from the side; $3_{2}$ : width of the caudal process in apical view (the width may differ); 4 : largest span between the ends of the caudal processes. (J) Diagram of neoactinomyxum spore in apical view (polar capsules not drawn). The spore is difficult to measure in side view once the caudal processes are swollen. 1. width of the spore body (angle to base); 2,3 : length and width of the caudal process respectively
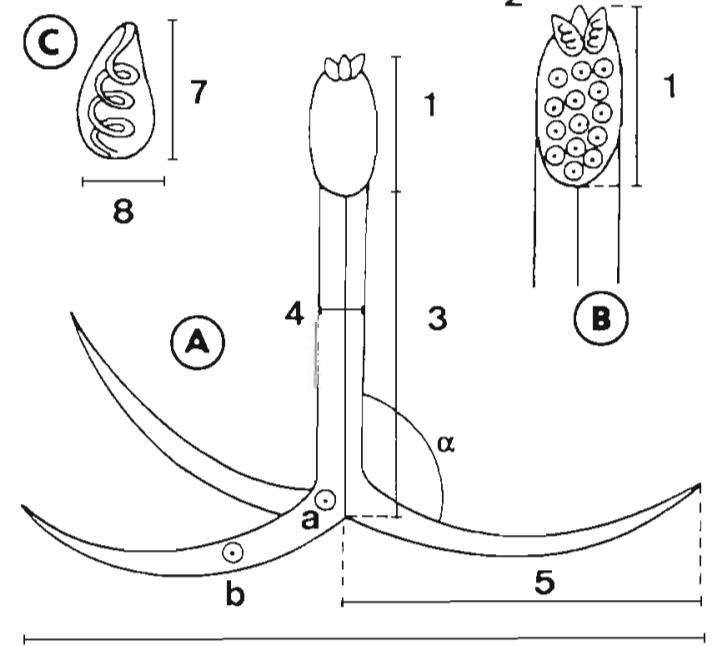

6
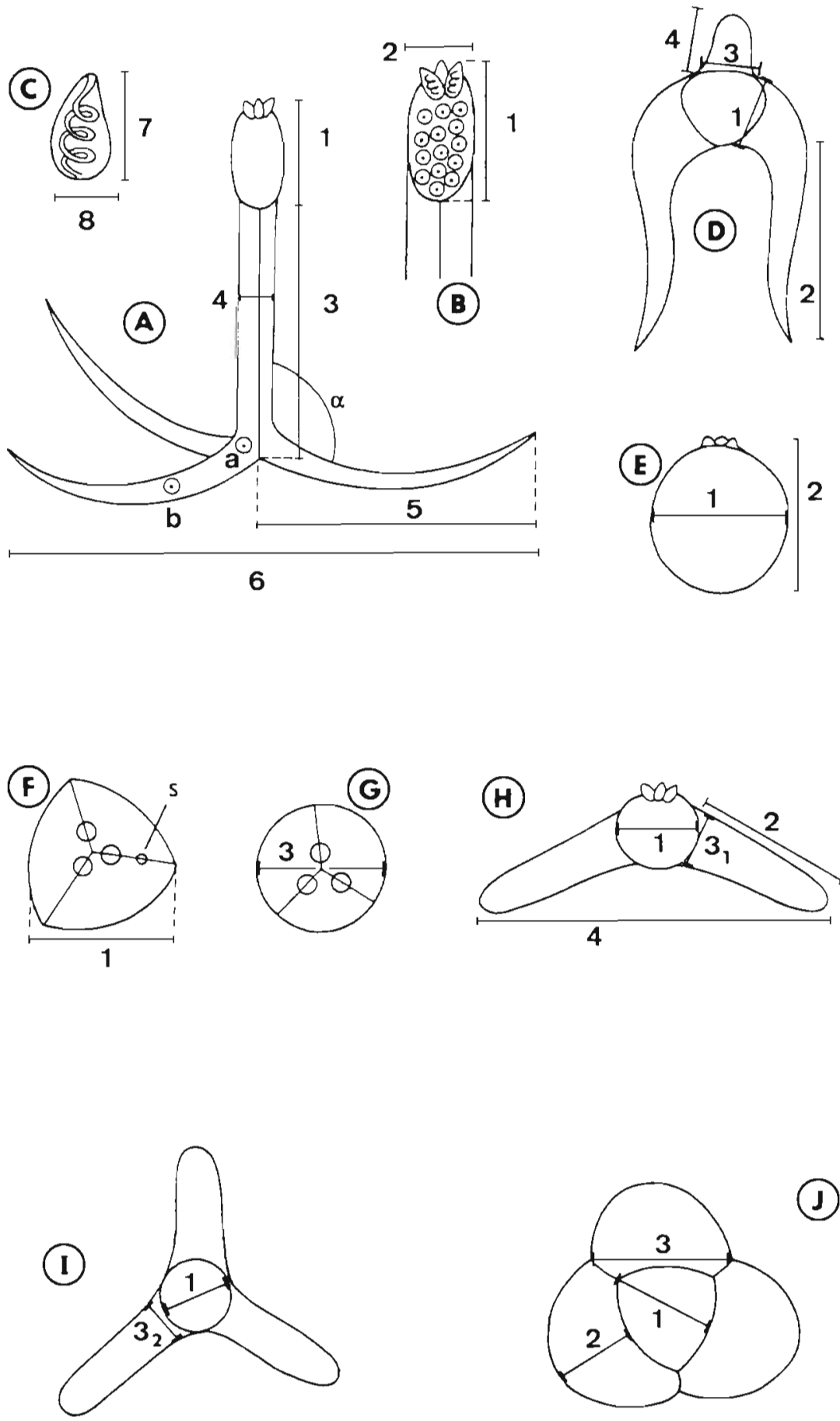

the sporoplasm should be regarded as a taxonomic character (Fig. 3).

Style: small stalk formed in some actinospores (e.g. triactinomyxon) by the fusion of the 3 valvogenic cells below the spore body. These cells may then separate and continue as caudal processes (Figs. 1A \& 2).

Valve cells: 3 cells that together form a cavity shel- tering the polar capsules and sporoplasm. They may have posterior or lateroposterior caudal processes which upon contact with water swell to a great length to function as floats. In some actinospores without such caudal processes, the valves themselves may swell to some extent. (An obsolete term for the whole of valve cells was 'epispore'). 


\section{GUIDELINES FOR ACTINOSPOREAN DESCRIPTIONS}

Host: determination of the species of oligochaete host can be difficult, especially if the worms concerned are not mature. The monographs of Brinkhurst (1963) and Brinkhurst \& Jamieson (1971) are particularly valuable for species identification.

Site of infection: e.g. intestinal epithelium between the epithelial or chloragogenic cells, or in the muscular layer, or in the coelomic cavity. Good histological sections or semi-thin sections taken during transmission electron microscopic (TEM) studies can be very useful in determining the localisation of infection.

Locality: geographic location, number of sites sampled, nature of the water body, substrate from which the worms were obtained, etc.

Pathogenicity: of special relevance may be any gross changes in the appearance of infected worms, e.g. opacity, which may be diagnostic of the presence of infection with certain actinosporeans.

Prevalence: often between 1 and $3 \%$, sometimes $<1 \%$. There are reports of 10 to $20 \%$ prevalence of Aurantiactinomyxon raabeiunioris in Limnodrilus hoffmeister (Marques 1984). Authors should make it clear whether prevalence has been calculated in terms of $\%$ infection in total number of worms (of all species) sampled or \% infection in only the oligochaete species which harbours infection with the actinosporean stage concerned. Any relevant information on seasonality should be presented, along with the dates on which samples were taken.

Myxosporean stage: this should be given if known. Where the myxosporean stage is not known, authors in some instances may have a thorough knowledge of the fish species present in the water body concerned, and/or of the myxosporean fauna of those fish. In these cases authors may consider providing a brief, concise summary of this data if they feel it valuable and are sure that it will not lead to confusion.

\section{Light microscope features (Figs. 1-7)}

Measurements: the dimension parameters to be measured for various forms of actinospore are provided in Fig. 1. Features to be included are size of: polar capsules (and the number of polar filament turns within them); style; caudal processes; spore body. The number of spores measured ( $n$ ) should be given along with mean values for the various parameters. Authors should state whether the actinospores were obtained from one worm or several. The degree of variation in dimensions should be expressed in terms of range or standard deviation from the mean.

Material: fresh material or photomicrographs of such material are essential for the measurement of actinospore dimensions. If fixed spores must be used, for example in the case of rare material, then the method of fixation should be given. Once fixed within the host, however, the spore material is of no value.

Photomicrographs/drawings: Representative drawings and photomicrographs should always accompany any description as these are essential to ensure satisfactory reidentification. Fixed material may also be deposited in an appropriate zoological collection.

Caudal processes: are they straight/curved/tapered/ branched?

Spore nets/webs: many actinospore forms (e.g. synactinomyxon) form nets or webs of spores on release (Fig. 4). The exact nature of the pattern in which the spores connect and the resultant shape they take can be difficult to ascertain, but if possible should be presented diagrammatically with the information 'how viewed'.

Pansporocyst outer dimension: this feature can differ considerably between actinosporeans and can be measured upon release from the host in fresh preparations or as measured in histological sections.

Suture line: is the suture line between the shell valves distinct, detectable or difficult to detect? The use of phase contrast and Nomarski interference contrast objectives can aid in observing this and other spore structures.

Sporoplasm structure: the number of inner, daughter cells can often be discerned in fresh mounts of some actinosporeans or in Giemsa stained smears. This number is a diagnostic feature in some groups (e.g. triactinomyxon). In other actinosporeans they can be more difficult to discern, especially in fresh preparations.

Presence of polysaccharide reserves: the presence of polysaccharide reserves in the sporoplasm is detectable by the use of Lugol's iodine.

Figs. 2 to 7. Bright field and phase-contrast micrographs. Fig. 2. Fresh triactinomyxon spore in side view. $(\times 270)$. Fig. 3. Spore body from Fig. 2 enlarged to show the position of polar capsules and numerous secondary cells within the sporoplasm. $(\times 770)$. Fig. 4. Synactinomyxon longicauda sp. inq. spores to illustrate a spore web. $(\times 400)$. Fig. 5. Fresh aurantiactinomyxon spore in apical view. Small arrow points at the suture; large arrow points at the nucleus inside the valve cell projection. $(\times 1000)$. Fig. 6. Early pansporocyst of raabeia with 8 zygotes. $(\times 1200)$. Fig. 7. Fresh mature pansporocysts of triactinomyxon released from its host. $(\times 230)$ 


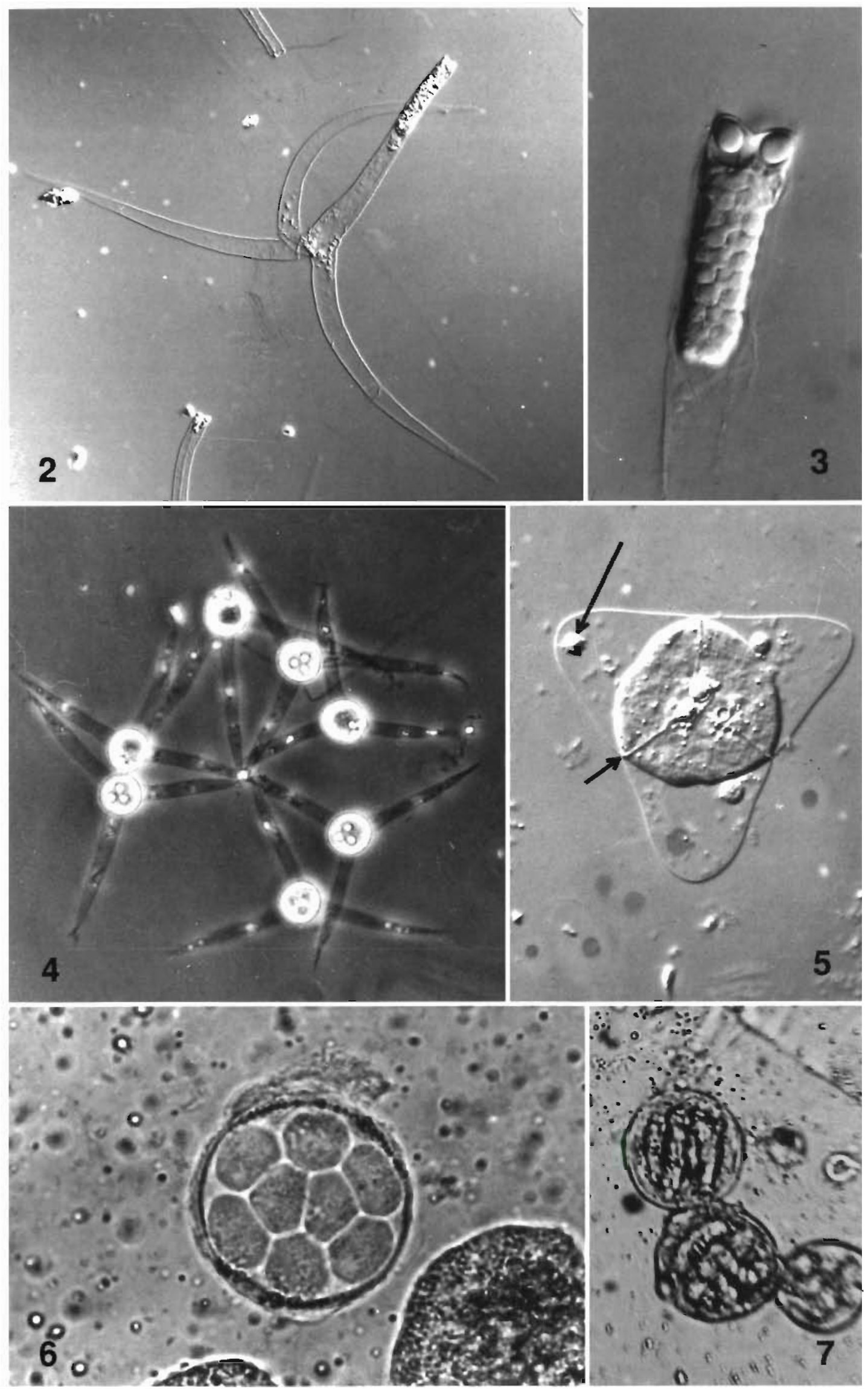




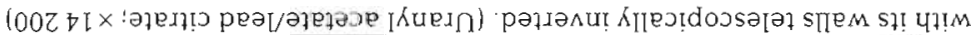

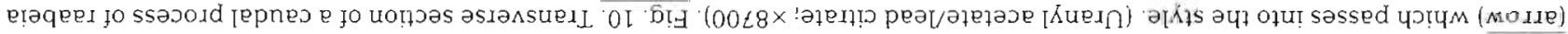

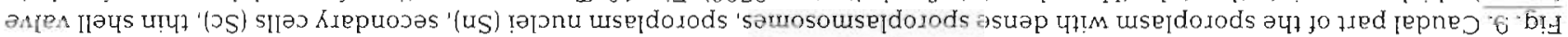

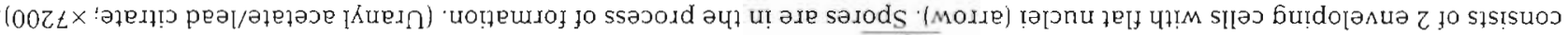

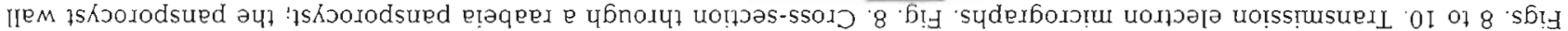

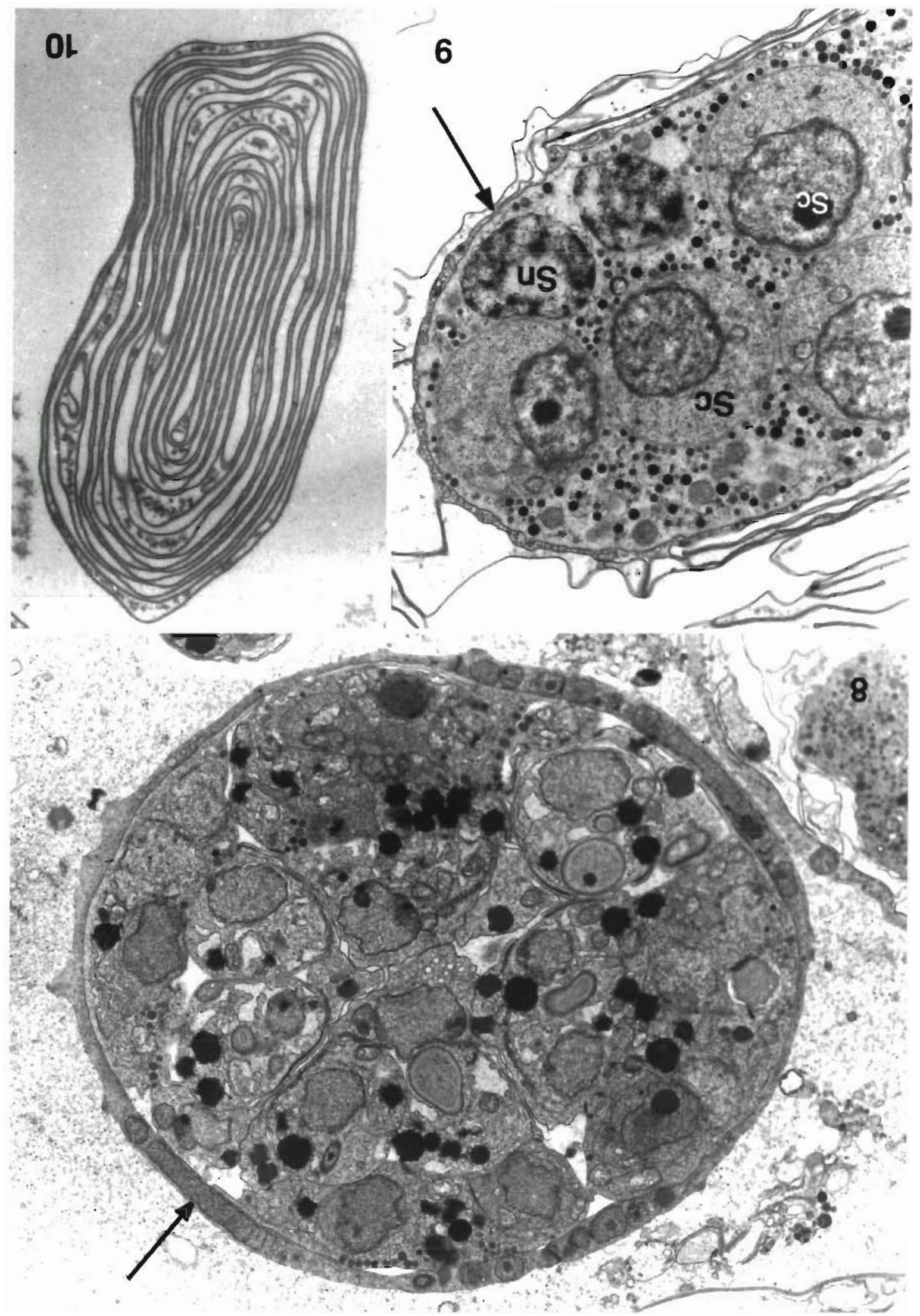


Transmission electron microscope features (Figs. 8-10)

Appearance of early stages: do these consist of uninucleate cells or binucleate cells? Is there evidence of presporogonic proliferation of early stages?

Number of cells forming the pansporocyst envelope: 2 cells or 4 ? (Fig. 8).

Position of vegetative nuclei: in the sporoplasm these can be either loose in the cytoplasm, or commonly closely associated with daughter cells (Fig. 9).

Sporoplasmosomes: size/structure/variability (Fig. 9).

\section{DISCUSSION}

A list of actinosporean descriptions to date is appended (Appendix 2). This should provide a starting point for comparing newly identified actinospores with descriptions already in the literature. The thesis of Marques (1984) contains a useful summary of reports to that date. In some cases, new forms of actinosporean are likely to be encountered for which the myxosporean stage remains unknown. It is vital in such instances that the new form is unambiguously named and characterised. This presents a problem since existing actinosporean specific names are to be suppressed once the myxosporean phase has been identified (Kent et al. 1994). In reports it therefore seems appropriate to employ the following system when making such descriptions. If, for example, a previously unreported actinosporean of the former genus Triactinomyxon is found in the future, it would be reported in vernacular as simply 'triactinomyxon actinosporean stage'. To ensure that future workers would be subsequently able to refer to such stages unambiguously, it is imper- ative that the authority in each instance be quoted (e.g. 'triactinomyxon actinosporean stage of Marques $1984^{\prime}$ ). If in a paper more than 1 stage of a particular actinosporean type were described, these could be consecutively numbered (e.g. neoactinomyxum stage no. $1,2, \ldots$ or $A, B, C \ldots$ etc. of Smith 1996).

Odening (1991) suggested that changes in terminology within the Myxozoa were required to reflect the role of oligochaetes as definitive hosts (e.g. the replacement of the term myxospore with myxogametophore, and pansporoblast with pangamoblast). On the basis of what is currently known about myxozoan sexual processes and considering the fact that studies of the transformative life cycle are in their infancy, these terms should perhaps not be used for the present. However they may prove to be useful as more knowledge accumulates on the life cycle, biology and sexual processes of myxozoans and more transformative life cycles are proven.

It is important to confront the level of information that can be obtained during experimental studies with that which can be obtained during faunistic studies of wild oligochaete populations. In experimental systems much information on developmental sequence and timing, spore release dynamics etc. should be available. However in wild studies, infection levels may be extremely low - many forms perhaps only being encountered as infections of single worms. In such studies it is inevitable that there will be gaps in knowledge.

The guidelines provided should enable the production of actinosporean descriptions which allow for safe reidentification.

Acknowledgements. The authors acknowledge the technical assistance of Mrs Hilary McEwen.

Appendix 1. Actinosporeans for which the myxosporean is known

\begin{tabular}{|lll|}
\hline Actinospore & Myxozoan species & Source \\
\hline Triactinomyxon & Myxobolus cerebralis & Wolf \& Markiw (1984) \\
Triactinomyxon & Myxobolus cotti & El-Matbouli \& Hoffmann (1989) \\
Hexactinomyxon & Myxobolus pavlovskii & Ruidisch et al. (1991) \\
Raabeia & Myxobolus cultus & Yokoyama et al. (1991) \\
& Myxobolus arcticus & Yokoyama et al. (1995) \\
Triactinomyxon & Myxobolus carassii & Kent et al. (1993) \\
Triactinomyxon & Hoferellus carassii & El-Matbouli et al. (1993) \\
Aurantiactinomyxum & Hoferellus carassii & El-Matbouli et al. (1992b) \\
Neoactinomyxum & Hoferellus cyprini & Yokoyama et al. (1993) \\
Aurantiactinomyxon/guyenotia? & PGD myxosporean & Großheider \& Körting (1992) \\
Aurantiactinomyxon & Ceratomyxa shasta & Styer et al. (1991) \\
Neoactinomyxum & Zschokella sp. & Bartholomew et al. (1992) \\
Siedleckiella & Myxidium giardi & Uspenskaya (1995) \\
Aurantiactinomyxon & Henneguya sp. & Benajiba \& Marques (1993) \\
$?$ & Myxobolus sp. & Hedrick et al. (1989) \\
$?$ & & Hedrick et al. (1989) \\
\hline
\end{tabular}


Appendix 2. Actinosporeans described as independent species for which the myxosporean stage is unknown

\begin{tabular}{|c|c|}
\hline \multicolumn{2}{|c|}{ Actinospore } \\
\hline $\begin{array}{l}\text { Synactinomyxon tubificis } \\
\text { Synactinomyxon longicauda }\end{array}$ & $\begin{array}{l}\text { Stolc (1899) } \\
\text { Marques \& Ormieres (1982) }\end{array}$ \\
\hline $\begin{array}{l}\text { Hexactinomyxon psammoryctis } \\
\text { Hexactinomyxon hedvigi }\end{array}$ & $\begin{array}{l}\text { Stolc (1899) } \\
\text { Janiszewska (1955) }\end{array}$ \\
\hline $\begin{array}{l}\text { Triactinomyxon ignotum } \\
\text { Triactinomyxon sp. } \\
\text { Triactinomyxon magnum } \\
\text { Triactinomyxon legeri } \\
\text { Triactinomyxon mrazeki } \\
\text { Triactinomyxon ohridensis } \\
\text { Triactinomyxon petri } \\
\text { Triactinomyxon naidanum } \\
\text { Triactinomyxon robustum } \\
\text { Triactinomyxon sp. } \\
\text { Triactinomyxon dubium } \\
\text { Triactinomyxon sp. }\end{array}$ & $\begin{array}{l}\text { Stolc (1899) } \\
\text { Léger (1904) } \\
\text { Granata (1922) } \\
\text { Mackinnon \& Adam (1924) } \\
\text { Mackinnon \& Adam (1924) } \\
\text { Georgevitch (1940) } \\
\text { Georgevitch (1940) } \\
\text { Naidu (1956) } \\
\text { Marques (1984) } \\
\text { Naidu (1956) } \\
\text { Granata (1925) [actinosporean stage of Myxobolus cerebralis] } \\
\text { Marques \& Ormieres (1982) }\end{array}$ \\
\hline $\begin{array}{l}\text { Sphaeractinomyxon stolci } \\
\text { Sphaeractinomyxon gigas } \\
\text { Sphaeractinomyxon danicae } \\
\text { Sphaeractinomyxon ilyodrili } \\
\text { Sphaeractinomyxon amanieui } \\
\text { Sphaeractinomyxon rotundum } \\
\text { Sphaeractinomyxon sp. } \\
\text { Actinomyxidiasp. }\end{array}$ & $\begin{array}{l}\text { Caullery \& Mesnil (1904) } \\
\text { Granata (1923) } \\
\text { Georgevitch (1938) } \\
\text { Jirovec }(1940) \\
\text { De Puytorac }(1963) \\
\text { Marques }(1984) \\
\text { Hallet (1995) } \\
\text { Kofoid (1908) }\end{array}$ \\
\hline $\begin{array}{l}\text { Neoactinomyxum globosum } \\
\text { Neoactinomyxum eiseniellae } \\
\text { Neoactinomyxum minutum }\end{array}$ & $\begin{array}{l}\text { Granata (1922) } \\
\text { Ormieres \& Frezil (1969), Marques (1984) } \\
\text { Marques (1984) }\end{array}$ \\
\hline Guyenotia sphaerulosa & Naville $(1930)$ \\
\hline Siedleckiella silesica & Janiszewska (1952) \\
\hline Antonactinomyxon antonii & Janiszewska (1954), Janiszewska (1957) \\
\hline $\begin{array}{l}\text { Raabeia gorlicensis } \\
\text { Raabeia magna } \\
\text { Raabeia furciligera }\end{array}$ & $\begin{array}{l}\text { Janiszewska (1955) } \\
\text { Janiszewska (1957) } \\
\text { Janiszewska \& Krzton (1973) }\end{array}$ \\
\hline $\begin{array}{l}\text { Aurantiactinomyxon raabeilunioris } \\
\text { Aurantiactinomyxon pavinsis } \\
\text { Aurantiactinomyxon stellans } \\
\text { Aurantiactinomyxon trifolium } \\
\text { Aurantiactinomyxon sp. A } \\
\text { Aurantiactinomyxon sp. B }\end{array}$ & $\begin{array}{l}\text { Janiszewska (1952) } \\
\text { Marques (1984) } \\
\text { Marques (1984) } \\
\text { Marques (1984) } \\
\text { Ormieres (1968) } \\
\text { Ormieres (1969) }\end{array}$ \\
\hline $\begin{array}{l}\text { Echinactinomyxon radiatum } \\
\text { Echinactinomyxon astilum } \\
\text { Echinactinomyxon sp. } \\
\text { Echinactinomyxon sp. }\end{array}$ & $\begin{array}{l}\text { Janiszewska (1957) } \\
\text { Janiszewska (1964), Marques (1984) } \\
\text { Marques \& Ormieres (1981) } \\
\text { Marques \& Ormieres (1982) }\end{array}$ \\
\hline Ormieractinomyxon racemosum & Marques (1984) \\
\hline
\end{tabular}

\section{LITERATURE CITED}

Bartholomew JL, Fryer JL, Rohovec JS (1992) Ceratomyxa shasta infections of salmonid fish. In: Kimura T (ed) Proceedings of the Oji International Symposium of Salmonid Diseases, Sapporo, Japan, 21-25 October, p 267-275

Benajiba $\mathrm{MH}$, Marques A (1993) The alternation of actinomyxidian and myxosporidian sporal forms in the development of Myxidium giardi (parasite of Anguilla anguilla) through oligochaetes. Bull Eur Assoc Fish Pathol 13: $100-103$

Brinkhurst RO (1963) A guide for the identification of British aquatic Oligochaeta. Freshwat Biol Assoc Sci Publ 22
Brinkhurst RO, Jamieson BGM (1971) Aquatic Oligochaeta of the world. Oliver \& Boyd, Edinburgh

El-Matbouli M, Fischer-Scherl T, Hoffmann RW (1992a) Present knowledge on the life cycle, taxonomy, pathology, and therapy of some Myxosporea spp. important for freshwater fish. Annu Rev Fish Dis 2:367-402

El-Matbouli M, Fischer-Scherl T, Körting W (1992b) Transmission of Hoferellus carassii Achmerov, 1960 to goldfish Carassius auratus via an aquatic oligochaete. Bull Eur Assoc Fish Pathol 12:54-56

El-Matbouli M, Hoffmann RW (1989) Expenmental transmission of two Myxobolus spp. developing bisporogeny via tubificid worms. Parasitol Res 75:461-464 
El-Matbouli M Hoffmann RW (1993) Myxobolus carassii Klokaceva, 1914 also requires an aquatic oligochaete. Tubifex tubifex as an intermediate host in its life cycle. Bull Eur Assoc Fish Pathol 13:189-192

El-Matbouli M, Hoffmann RW, Mandok C (1995) Light and electron microscopic observations on the route of the triactinomyxon-sporoplasm of Myxobolus cerebralis from epidermis into rainbow trout cartilage. J Fish Biol 46: $919-935$

Großheider G, Korting W (1992) First evidence that Hoferellus cyprini (Doflein, 1898) is transmitted by Nass sp. Bull Eur Assoc Fish Pathol 12:17-20

Hedrick RP, Wishkovsky A, Groff JM, McDowell T (1989) Transmission trials with three myxosporeans of salmonid fish. In: Diseases of fish and shellfish. IVth Conference of the European Association of Fish Pathologists, Santiago de Compostela, Spain 24-28 September 1989. (abstract 38)

Janiszewska J (1957) Actinomyxidia II. New systematics, sexual cycle, description of new genera and species. Zool Pol 8:3-34

Kent ML, Margolis L, Corliss JO (1994) The demise of a class of protists: taxonomic and nomenclatural revisions proposed for the protist phylum Myxozoa Grasse, 1970 Can J Zool 72:932-937

Kent ML, Whitaker DJ, Margolis L (1993) Transmission of Myxobolus arcticus Pugachev and Khokhlov, 1979, a myxosporean parasite of Pacific salmon, via a triactinomyxon from the aquatic oligochaete Stylodrilus heringianus (Lumbriculidae). Can J Zool 71:1207-1211

Lom J, Arthur JR (1989) A guideline for preparation of species descriptions in Myxosporea. J Fish Dis 12:151-156

Marques A (1984) Contribution à la connaissance des Actinomyxidies: ultrastructure, cycle biologique, systématique Thesis, Université des Sciences et Techniques de Languedoc, Montpellier

Odening $\mathrm{K}$ (1991) On the alternation of generations in myxosporidians/actinomyxidians (Myxosporidia). Zool Anz 226 $237-252$

Ruidisch S, El-Matbouli M, Hoffmann RW (1991) The role of tubificid worms as an intermediate host in the life cycle of Myxobolus pavlovskii Achmerov, 1954. Parasitol Res 77 $663-667$

Responsible Subject Editor: W. Körting, Hannover, Germany
Schlegel M, Lom J, Stechmann A, Bernhard D, Leipe D Dyková I, Sogin ML (1996) Phylogenetic analysis of complete small subunit ribosomal RNA coding region of $M_{Y X-}$ idium lieberkuehni: evidence that the Myxozoa are metazoans and related to bilaterians. Arch Protıstenkd 147:1-9

Siddal ME, Martin DS, Bridge D. Desser SS, Cone DK (1995) The demise of a phylum of protists: phylogeny of Myxozoa and other parasitic Cnidaria. J Parasitol 81:961-967

Smothers JF, von Dohlen CD, Smith LH, Spall RD (1994) Molecular evidence that the myxozoan protists are metazoans Science 265:1719-1721

Styer EL, Harrison LR, Burtle GJ (1991) Experimental production of proliferative gill disease in channel catfish exposed to a myxozoan-infected oligochaete, Dero digitata. J Aquat Anim Health 3:288-291

Urawa S, Yokoyama H, Kent ML, Margolis L (1995) Geographical variation in morphology and host susceptibility in actinosporeans of Myxobolus arcticus. IVth International Symposium of Fish Parasitology, October 3-7, University of Munich (abstract)

Uspenskaya AV (1995) Alternation of actinosporean and myxosporean phases in the life cycle of Zschokkella nova (Myxozoa). J Eukaryot Microbiol 42:665-668

Wolf K, Markiw ME (1984) Biology contravenes taxonomy in the Myxozoa: new discoveries show alternation of invertebrate and vertebrate hosts. Science 225:1449-1452

Yokoyama H. Ogawa K, Wakabayashi H (1991) A new collection method of actinosporeans - a probable infective stage of myxosporeans to fishes-from tubificids and experimental infection of goldfish with the actinosporean, Raabeia sp. Gyobyu Kenkyu 28:135-139

Yokoyama H, Ogawa K, Wakabayashi H (1993) Involvement of Branchiura sowerbyi (Oligochaeta: Annelida) in the transmission of Hoferellus carassin (Myxosporea: Myxozoa), the causative agent of kidney enlargement disease (KED) of goldfish Carassius auratus. Gyobyo Kenkyu 28:135-139

Yokoyama H, Ogawa H, Wakabayashi H (1995) Myxobolus cultus n. sp. (Myxosporea: Myxobolidae) in the goldfish Carassius auratus transformed from the actinosporean stage in the oligochaete Branchiura sowerbyi. J Parasitol 81:446-451

Manuscript received: August 7,1996

Revised version accepted: March 10, 1997 